\title{
Potential protective effect of Tualang honey on BPA-induced ovarian toxicity in prepubertal rat
}

\author{
Siti Sarah Mohamad Zaid ${ }^{1,3}$, Shatrah Othman ${ }^{2}$ and Normadiah M Kassim ${ }^{1 *}$
}

\begin{abstract}
Background: To investigate the potential protective effects of Tualang honey against the toxicity effects induced by Bisphenol A (BPA) on pubertal development of ovaries.

Methods: This study was conducted on pre-pubertal female Sprague Dawley rats. Animals were divided into four groups ( $n=8$ in each group). Group I was administered with vehicle $0.2 \mathrm{ml}$ of corn oil (Sigma-Aldrich, USA) using oral gavage daily for six weeks; these animals served as negative control (CO group), Group II was administered with BPA suspended in corn oil at $10 \mathrm{mg} / \mathrm{kg}$ body weight and served as positive control (PC group), Group III was administered with $200 \mathrm{mg} / \mathrm{kg}$ body weight of Tualang honey $30 \mathrm{~min}$ before the administration of BPA at $10 \mathrm{mg} / \mathrm{kg}$ (TH group) while Group IV was administered with $200 \mathrm{mg} / \mathrm{kg}$ body weight of Tualang honey $30 \mathrm{~min}$ before the administration of corn oil (THC group). Body weight of all animals were monitored weekly.
\end{abstract}

Results: The BPA-exposed animals exhibited disruption of their estrus cycle, while those animals treated with BPA together with Tualang honey, exhibited an improvement in percentage of normal estrous cycle. Their ovaries had lower numbers of atretic follicles compared to the PC group but higher than the CO group.

Conclusions: Tualang honey has a potential role in reducing BPA-induced ovarian toxicity by reducing the morphological abnormalities of the ovarian follicles and improving the normal estrous cycle.

Keywords: Tualang honey, Bisphenol-A, Ovary, Toxicity, Antioxidant

\section{Background}

In recent years, environmental toxicants have become a serious health concern. It has caused a rise in concern when exposure of endocrine-disrupting chemicals (EDCs) on human and wildlife has effects on the reproduction development and function [1,2]. One of the EDCs is bisphenol A that is widely used in industries as plasticizer for the production of polycarbonate plastics and epoxy resins [3]. In daily life, bisphenol A is widely used in numerous products including digital media (CDs and DVDs), electronic equipment, automobiles, construction glazing, sports safety equipment, medical devices, tableware, reusable bottles, toys, water pipes and food containers $[4,5]$. The dramatic increase of bisphenol A exposure in humans were detected in serum, follicular fluid and amniotic fluid [6], fetal serum [7], milk of nursing mother $[8]$ and urine $[9,10]$. These findings have

\footnotetext{
* Correspondence: normadiah_mk@um.edu.my

${ }^{1}$ Department of Anatomy, Faculty of Medicine, University of Malaya, 50603

Kuala Lumpur, Malaysia

Full list of author information is available at the end of the article
}

resulted in both scientific and public interests in assessing bisphenol A as a potential EDCs to health risk.

Several studies have reported that bisphenol A could induce morphological and functional alterations of the female genital system, especially in the ovaries at low presumably environmentally relevant doses [11]. In vitro studies claimed that bisphenol A negatively affects granulosa cell steroidogenesis by altering the steroidogenic enzymes and stimulatory effects on vascular endothelial growth factor (VEGF) that cause uncontrolled neovascularization [5,12]. Subsequently, these findings suggest that these cells are highly sensitive to bisphenol A. Other in vivo studies also indicated that neonatal exposure to bisphenol A reduced the pool of primordial follicles in rats [13] while in mice, prenatal exposure to bisphenol A caused increased antral follicles but reduced corpora lutea percentages [14]. Moreover, development of polycystic ovaries (PCOS) [15] and decreased luteinizing hormone (LH) were observed [16]. Bisphenol A exposure has been claimed to promote oxidative stress (OS) and 
inflammation in women [17]. Treatment with bisphenol A induced OS in various tissues of rodent [18] by decreasing antioxidant enzymes and increasing hydrogen peroxide and lipid peroxidation [19]. Several compounds with antioxidant properties have been studied extensively as a method to counter disease-associated OS [20]. With these concerns in mind, many studies have been focusing on the possible therapeutic and preventive measures to counter the effects of deleterious effects of bisphenol A on the reproductive system.

Tualang honey, a wild Malaysian honey, contains high antioxidant properties [21-24]. It has been shown to ameliorate OS in renal and pancreas of streptozotocininduced diabetic rat $[25,26]$. It was also reported to prevent uterine and vaginal atrophy [27] as well as prevent osteoporosis of bones [28], protects rat testis against damage and OS induced by cigarette smoke [29]. It was also reported to have antiproliferative effects on oral squamous cell carcinomas (OSCC), human osteosarcoma (HOS) [30] and keloid fibroblasts [31]. The beneficial effects in those positive findings were claimed to be due to the antioxidant properties of Tualang honey.

The aim of the present study was to investigate the effects of bisphenol A administered during prepubertal period on ovarian follicular development, estrous cyclicity and hormonal profile. Consequently, the protective effects of Tualang honey against the deleterious effects of bisphenol A toxicity on ovarian follicular development, estrous cyclicity and hormonal profile were investigated.

\section{Methods}

\section{Tualang honey (Agromas, Malaysia)}

Tualang honey, a wild multifloral honey was supplied by Federal Agricultural Marketing Authority (FAMA), under Ministry of Agriculture and Agro-Based Industry, Malaysia. It was collected from Apis dorsata's beehive built on a giant tree (tall and big), Koompassia excels (locally known as Tualang tree) that grows in the rain forest of Kedah, Malaysia. The honey was filtered to remove solid particles, concentrated in an oven at $40^{\circ} \mathrm{C}$ and subjected to $\gamma$ irradiation at $25 \mathrm{kGy}$ at Sterilgamma (M) Sdn. Bhd. (Selangor, Malaysia). The water concentration of the honey was standardized by FAMA at $18 \%$.

\section{Animal and experimental design}

Thirty-two prepubertal female Sprague Dawley rats aged 21 (P21) days were obtained from the Animal Husbandry, Faculty of Medicine, University of Malaya. The experimental design and procedures were conducted under protocols in compliance with EU Directive 2010/63/EU that approved by the Animal Care and Committee (ACUC) of University of Malaya. The animals were maintained under the standard laboratory conditions (temperature $25 \pm 2{ }^{\circ} \mathrm{C}$, $50 \pm 15 \%$ relative humidity and normal photoperiod of
$12 \mathrm{~h}$ dark and $12 \mathrm{~h}$ light) with free access to rat commercial pellet diet (Gold Coin Feedmills Pte. Ltd, Malaysia) and water ad libitum. To minimize additional exposures to EDCs, water was supplied in glass bottles with rubber stoppers surrounded by a steel ring. They were acclimatized to the laboratory environment for a week prior to the commencement of the experiments. At P28, the animals were weighed and randomly divided into four groups ( $\mathrm{n}=8$ in each group). Group I was administered with vehicle $0.2 \mathrm{ml}$ of corn oil (Sigma-Aldrich, USA) and served as negative control (CO group). Group II was administered with BPA (Sigma Aldrich, USA) suspended in corn oil at $10 \mathrm{mg} / \mathrm{kg}$ body weight and served as positive control (PC group). Group III was administered with $200 \mathrm{mg} / \mathrm{kg}$ body weight of Tualang honey $30 \mathrm{~min}$ before the administration of BPA at $10 \mathrm{mg} / \mathrm{kg}$ (TH group). Group IV was administered with $200 \mathrm{mg} /$ $\mathrm{kg}$ body weight of Tualang honey $30 \mathrm{~min}$ before the administration of corn oil (THC group). The treatment was performed in the morning (between 09:00 and 10:00 AM) once daily by oral gavage (to mimic the most likely route of human exposure) for six consecutive weeks.

Tualang honey was freshly prepared every morning (to avoid oxidation of the antioxidants) by dissolving in deionized water. Justification for dose selection of BPA was based on previous studies (influenced morphological and biochemical parameters in reproductive system) [32-35]. The dose of Tualang honey used was based on previous study which showed positive biological effects on female reproductive organs and the dose used was equivalent to routine/normal dose (one table spoon) in adult human [27]. Throughout the administration period, daily body weight was recorded while vaginal smear was taken to determine the estrous phase. After the last treatment, the animals were sacrificed. Venous blood samples were collected by direct heart puncture under deeply ketamine anaesthesia (Troy Laboratories, Australia). Serum from blood samples were store at $-80^{\circ} \mathrm{C}$ until analysis. The ovaries were weighed and immediately fixed in $10 \%$ buffered formalin for histopathological analysis.

\section{Histopathological analysis}

The harvested ovaries were fixed by immersion in $10 \%$ buffered formalin for 24 hours. Subsequently, the ovaries were hydrated in a graded series of ethanol, clearance by xylene, embedded in paraffin and sectioned. Serial sections (5 $\mathrm{m}$ thickness) at were obtained and mounted onto glass slide, deparaffinized in xylene, stained with hematoxylin and eosin (Sigma Aldrich, USA) and dehydrated in a graded series of ethanol, cleared in xylene and mounted with Canada Balsam (Sigma-Aldrich). Histopathological changes and morphometric analysis in each ovarian section was performed on 62 total fields areas that were measured with grid lines using NIS-Elements 
software. All sections were observed under a light microscope (Olympus $\mathrm{CH}-\mathrm{B} 145-2)$ attached to image analyzer (NIS-Elements Advanced Research, Nikon, Japan).

\section{Classification and quantification of ovarian follicles}

Ovarian follicles were classified and counted according to the criteria described by Zhuang et al. [36] as follows:

i) Primary follicles: an oocyte surrounded by a single layer of cuboidal granulose cells in part or in entirety.

ii) Secondary follicles: surrounded by more than one layer of cuboidal granulose cells with no visible antrum.

iii) Antral follicles: identified by the presence of an antral space and cumulus granulose cell layer.

iv) Corpus luteum: formed only after ovulation and filled with lutein cells.

v) Atretic follicles: had abnormal structures such as inspissated follicular fluid, degenerated egg, disorganized and thickened granulosa layers or filled with organizing fibrinous material in the antrum.

\section{Assessment of estrous cycles}

Estrous cycles of rats were determined by daily observation of vaginal smears (between 09:00 and 10:00 AM). Vaginal secretion was collected using a plastic pipette filled with approximately $0.2 \mathrm{ml}$ of normal saline $(\mathrm{NaCl}$ $0.9 \%)$. The tip of the pipette was inserted into the vagina to a depth of 2-5 $\mathrm{mm}$. Then, the normal saline was flushed into the vagina and returned into the pipette by gently squeezing and releasing the bulb of the pipette. These steps were repeated for three times before the sample was collected. Subsequently, a drop of the cell suspension was smeared onto a labelled glass slide. Unstained smear was observed under a light microscope, without the use of the condenser lens, with $10 \mathrm{x}$ and $40 \mathrm{x}$ objective lenses. The cytological appearance of vaginal smears determined the phase of the estrous cycle as follows:

The proestrous phase (twelve to fourteen hours) was defined by the predominance of nucleated epithelial cells; an estrous phase (twenty-five to twenty-seven hours) primarily consisted of anucleated cornified cells; a metestrous phase (six to eight hours) consisted of the same proportion among leucocytes, cornified and nucleated epithelial cells; and the diestrous phase (fifty-five to fifty-seven hours) primarily consisted of a predominance of leucocyctes.

The criteria implemented for determining cycle patterns:

1) Regular cycle (RC): denoted a 4 to 5-day estrous cycle in which the estrous phase was observed at least twice during the sampling period.

2) Persistent diestrous: or prolonged diestrous have four or more days of diestrous phase during most of the cycles.

\section{Assay of serum estradiol, FSH, LH and progesterone}

After two hours at room temperature, clotted blood samples were centrifuged at $1,000 \times \mathrm{g}$ for 15 minutes, extracted serum were stored at $-80^{\circ} \mathrm{C}$ until subsequent analysis. ELISA (Cusabio, USA) was used for measurement of the circulating levels of $17 \beta$-estradiol $\left(E_{2}\right)$, follicle stimulating hormones (FSH), luteinizing hormones ( $\mathrm{LH})$ and progesterone $\left(\mathrm{P}_{4}\right)$. Each sample was run in duplicate. In brief, $50 \mu \mathrm{l}$ each of the standards, control and serum samples were added to respective wells coated with estradiol $\left(\mathrm{E}_{2}\right)$, follicle stimulating hormones $(\mathrm{FSH})$, luteinizing hormones $(\mathrm{LH})$ or progesterone $\left(\mathrm{P}_{4}\right)$ antibody and incubated with $50 \mu \mathrm{l}$ of enzyme conjugate for two hours at $37^{\circ} \mathrm{C}$ in oven (Echo Therm, USA). Subsequently, the wells were rinsed three times with distilled water and $50 \mu$ of the substrate was added and incubated for 15 minutes at $37^{\circ} \mathrm{C}$. Reactions were terminated using $50 \mu$ of stop solution. The optical density (O.D) was measured at $450 \mathrm{~nm}$ using a microplate reader (BioTek, USA). For determination of each hormonal level, a standard curve was constructed by plotting a graph of the absorbance of each reference standard against its corresponding levels. The inter-assay and intra-assay variations were found to be less than $15 \%$.

\section{Statistical analysis}

All statistical evaluations were performed with Statistical Package for Social Sciences (SPSS Inc. Chicago, Illinois, USA version 18.0 for windows). Parametric variables (body weight, ovary weight, hormonal assay and follicular counting) were analyzed using one-way analysis of variance (ANOVA) followed by Bonferroni test for multiple comparisons to identify significant different between groups. Estrous cycle phase was analyzed with Fisher's exact probability test. Values are reported as mean \pm S.E.M. $\mathrm{P}<0.05$ was considered significant.

\section{Results}

\section{Body weight and ovary weight}

Analysis of body weight and the weight of selected organs in toxicological studies are sensitive indicators for adverse effects of treatments. Analysis of relative organ weight (normalized to absolute organ weight to body weight) is an important and accurate analytical endpoint for identification of harmful effects of chemicals on the organ weights [37]. The value of body weight gain, changes in body weight, ovary wet weight and ovary relative weight in experimental groups are shown in Table 1 . The mean body weight gain in each group was obtained from the difference in values between the final body weight (at P71) and the initial body weight (at P28). This body weight gain was divided by the final body weight (at P71) to obtain the percentage to obtain the percentage of body weight change. The changes in body weight in PC group and 
Table 1 Body weight and ovary weight in experimental groups

\begin{tabular}{lcccc}
\hline Group & Body weight gain $(\mathbf{g})$ & \% changes in body weight & Ovary wet weight $(\mathbf{g})$ & Ovary relative weight (mg/g body weight) \\
\hline CO & $78.88 \pm 14.61$ & $48.15 \pm 6.60$ & $36.88 \pm 1.88$ & $0.24 \pm 0.01^{\mathrm{b}}$ \\
PC & $99.25 \pm 9.90$ & $56.52 \pm 3.49$ & $49.38 \pm 1.13$ & $0.29 \pm 0.12^{\mathrm{a}}$ \\
TH & $92.50 \pm 4.62$ & $56.12 \pm 1.94$ & $40.00 \pm 1.64$ & $0.24 \pm 0.02^{\mathrm{b}}$ \\
THC & $89.5 \pm 10.64$ & $52.39 \pm 3.47$ & $38.75 \pm 0.82$ & $0.23 \pm 0.01^{\mathrm{bb}}$ \\
\hline
\end{tabular}

The data were presented as mean \pm S.E.M. Ovary relative weight with different superscripts are significantly different. ${ }^{\text {a }} \mathrm{P}<0.05$ versus negative control group (CO) and ${ }^{b} \mathrm{P}<0.05,{ }^{\mathrm{bb}} \mathrm{P}<0.01$ versus positive control group (PC). There were no significant changes in body weight between all groups.

$\mathrm{CO}=$ Negative control group administered with vehicle (corn oil).

$\mathrm{PC}=$ Positive control group administered with BPA at $10 \mathrm{mg} / \mathrm{kg}$ body weight.

$\mathrm{TH}=$ Tualang honey group administered with Tualang honey at $200 \mathrm{mg} / \mathrm{kg}$ body weight $+\mathrm{BPA}$ at $10 \mathrm{mg} / \mathrm{kg}$ body weight.

$\mathrm{THC}=$ Tualang honey control group administered with Tualang honey at $200 \mathrm{mg} / \mathrm{kg}$ body weight.

TH group were slightly higher than $\mathrm{CO}$ group. However, the difference was not significant. It was also noted that treatment with Tualang honey in BPA-exposed rats cannot prevent increase of body weight. The changes in body weight in THC group were comparable to $\mathrm{CO}$ group. The ovary relative weight in PC group was significantly higher than $\mathrm{CO}$ group. Interestingly, treatment with Tualang honey in BPA-exposed rat (TH group) showed significant reduction in body weight compared to the PC group.

\section{Estrous cycle}

Table 2 shows the estrous cycle patterns in all experimental groups. In $\mathrm{CO}$ group and THC groups, all rats maintained in normal estrous cycle. In PC group, only $37.5 \%$ presented normal estrous cycles and a higher percentage showed persistent diestrous (62.5\%). These estrous cycles pattern were significantly different with both $\mathrm{CO}$ group and THC group. However, treatment with Tualang honey in BPA-exposed rats showed higher percentage in normal estrous cycle $(62.5 \%)$ and lower in persistent diestrous (37.5\%) compared to PC group but not statistically different.

\section{Follicle stimulating hormone (FSH) and luteinizing} hormone (LH)

Serum FSH and LH levels were significantly reduced in PC group and $\mathrm{TH}$ group compared to $\mathrm{CO}$ group and $\mathrm{THC}$ group. It was also noted that Tualang honey treatment on
BPA-exposed rats cannot prevent the reduction of both hormones levels (Figures 1 and 2).

\section{$17 \beta$-Estradiol $\left(E_{2}\right)$ and progesterone $\left(P_{4}\right)$}

There were no significant change with regards to both $E_{2}$ and $\mathrm{P}_{4}$ levels in all experimental groups. However, the $\mathrm{E}_{2}$ level in PC group and TH group were slightly increased compared to the $\mathrm{CO}$ group (vehicle-treated). The reduction in the $\mathrm{P}_{4}$ level as seen in the PC group (BPA-treated) was slightly prevented with Tualang honey treatment (Figures 3 and 4).

\section{Ovarian follicular development}

Ovarian morphology analysis was conducted by qualitative and quantitative methods. Generally, ovaries from all groups displayed all stages of follicular development. Qualitative histological examination revealed that THC group exhibited healthy ovaries comparable to the ovaries of the negative control group (Figure 5). On the other hand, both the PC group and $\mathrm{TH}$ group showed some abnormalities of the ovaries with large antral-like follicles that did not arrive at ovulation and the presence of atretic cystic-like follicles. There was less number of corpus lutea observed. However, the degree of abnormalities was more apparent in the ovaries of the PC group compared to the $\mathrm{TH}$ group. Ovarian follicles at different stages were found in the ovaries of experimental groups. No significant difference was observed in the number of preantral, antral follicles and corpora lutea among all experimental groups

Table 2 Pattern of estrous cycle of rats from day 41 to day-70 in all experimental groups

\begin{tabular}{lll}
\hline Group & Number of rats with normal cycles (\%) & Persistent diestrous (\%) \\
\hline CO & $8(100 \%)^{\mathrm{b}}$ & $0^{\mathrm{b}}$ \\
PC & $3(37.5 \%)^{\mathrm{a}}$ & $5(62.5 \%)^{\mathrm{a}}$ \\
TH & $5(62.5 \%)$ & $3(37.5 \%)$ \\
THC & $8(100 \%)^{\mathrm{b}}$ & $0^{\mathrm{b}}$
\end{tabular}

The data were presented as number (percentage). Numbers with different superscripts are significantly different. ${ }^{\mathrm{a}} \mathrm{P}<0.05$ versus negative control group (CO) and ${ }^{\mathrm{b}} \mathrm{P}<0.05$ versus positive control group (PC).

$\mathrm{CO}=$ Negative control group administered with vehicle (corn oil).

$\mathrm{PC}=$ Positive control group administered with BPA at $10 \mathrm{mg} / \mathrm{kg}$ body weight.

$\mathrm{TH}=$ Tualang honey group administered with Tualang honey at $200 \mathrm{mg} / \mathrm{kg}$ body weight $+\mathrm{BPA}$ at $10 \mathrm{mg} / \mathrm{kg}$ body weight .

$\mathrm{THC}=$ Tualang honey control group administered with Tualang honey at $200 \mathrm{mg} / \mathrm{kg}$ body weight. 


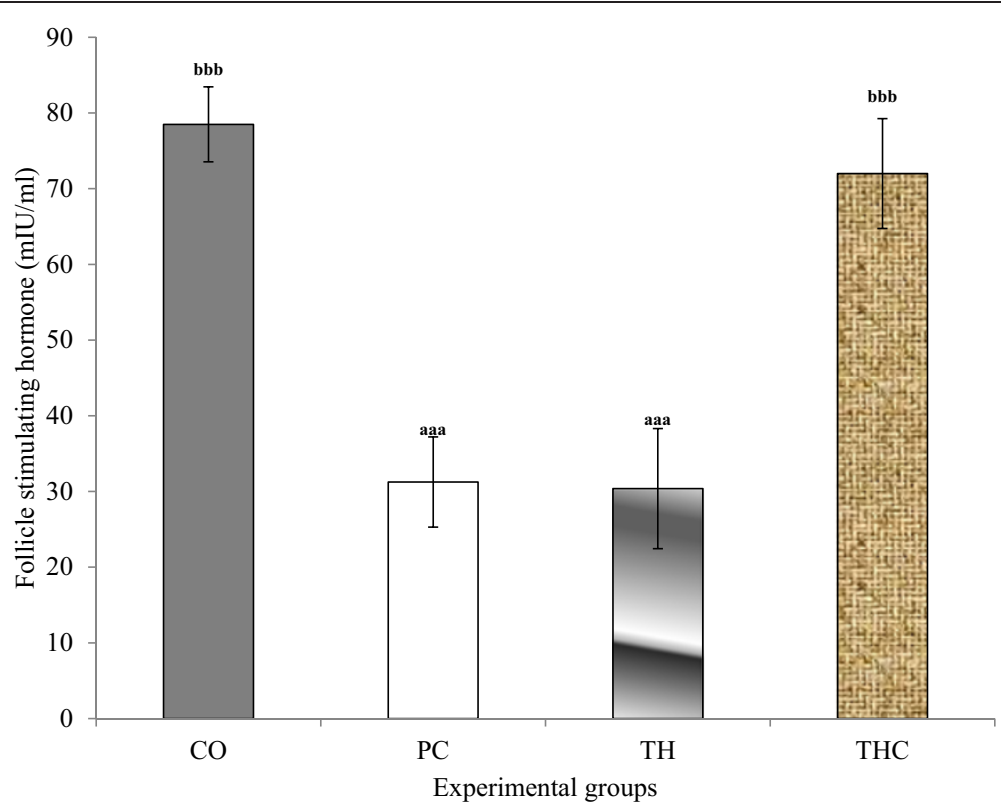

Figure 1 Serum follicle stimulating hormone (FSH) in all experimental groups. The data were presented as Mean \pm S.E.M. Mean with different superscripts are significantly different. ${ }^{a} \mathrm{P}<0.001$ versus negative control group (CO) and ${ }^{\mathrm{b}} \mathrm{P}<0.001$ versus positive control group (PC). $\mathrm{CO}=$ Negative control group administered with vehicle (corn oil). PC = Positive control group administered with BPA at $10 \mathrm{mg} / \mathrm{kg}$ body weight. $\mathrm{TH}=$ Tualang honey group administered with Tualang honey at $200 \mathrm{mg} / \mathrm{kg}$ body weight $+\mathrm{BPA}$ at $10 \mathrm{mg} / \mathrm{kg}$ body weight. THC = Tualang honey control group administered with Tualang honey at $200 \mathrm{mg} / \mathrm{kg}$ body weight.

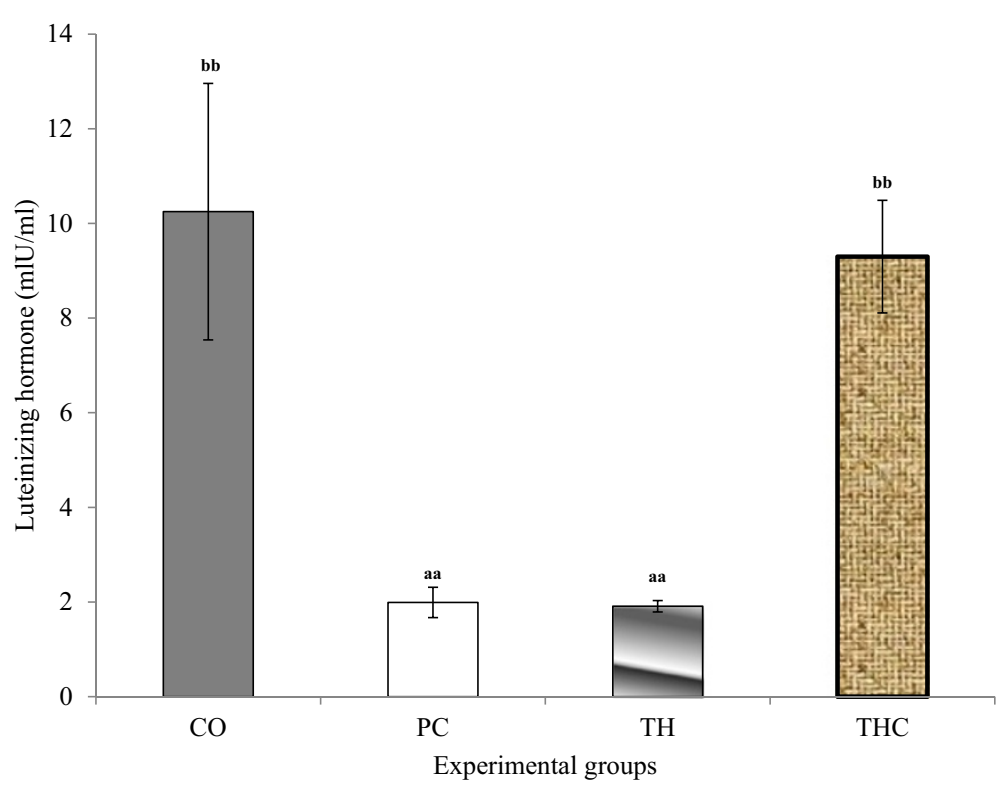

Figure 2 Serum luteinizing hormone (LH) levels in all experimental groups. The data were presented as Mean \pm S.E.M. Mean with different superscripts are significantly different ${ }^{\mathrm{a} P}<0.01$ versus negative control group (CO) and ${ }^{\mathrm{b}} \mathrm{P}<0.01$ versus positive control group (PC). CO = Negative control group administered with vehicle (corn oil). PC = Positive control group administered with BPA at $10 \mathrm{mg} / \mathrm{kg}$ body weight. TH=Tualang honey group administered with Tualang honey at $200 \mathrm{mg} / \mathrm{kg}$ body weight + BPA at $10 \mathrm{mg} / \mathrm{kg}$ body weight. THC = Tualang honey control group administered with Tualang honey at $200 \mathrm{mg} / \mathrm{kg}$ body weight. 


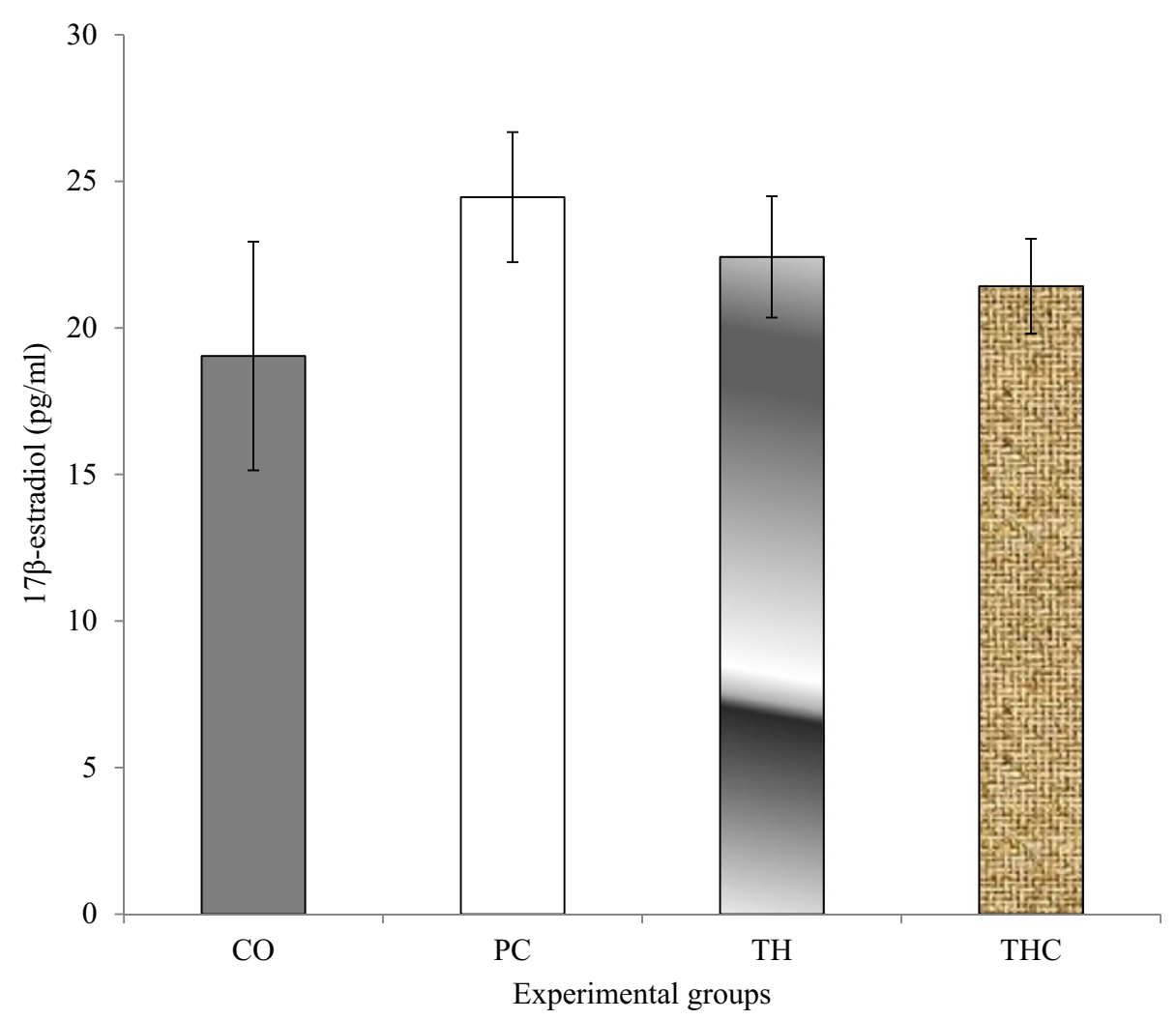

Figure 3 Serum estradiol $\left(E_{2}\right)$ levels in all experimental groups. The data were presented as mean \pm S.E.M. There were no significant differences in estradiol levels between all experimental groups. $\mathrm{CO}=$ Negative control group administered with vehicle (corn oil). $\mathrm{PC}=\mathrm{Positive}$ control group administered with BPA at $10 \mathrm{mg} / \mathrm{kg}$ body weight. TH=Tualang honey group administered with Tualang honey at $200 \mathrm{mg} / \mathrm{kg}$ body weight + BPA at $10 \mathrm{mg} / \mathrm{kg}$ body weight. THC = Tualang honey control group administered with Tualang honey at $200 \mathrm{mg} / \mathrm{kg}$ body weight.

(Figure 6). However, although not statistically different, the numbers of preantral follicles were lower in PC group and $\mathrm{TH}$ group compared to both control groups (CO group and THC group). The number of antral follicles were higher in PC group and $\mathrm{TH}$ group compared to both control groups. However, the numbers of antral follicles in $\mathrm{TH}$ group was slightly lower than PC group. Similar trend as in preantral follicles was also observed in the numbers of corpus luteum follicles. Only the number of atretic follicles in PC group and TH group were significantly higher than both control groups. However, the numbers of atretic follicles in $\mathrm{TH}$ group was slightly lower than PC group.

\section{Discussion}

The prepubertal period is a crucial time during child development. According to the schedule of comparative age categories based on reproductive development in rat and human [38] the child period (post-weaning age) in rat begins at 21-day to 45-day of age which is 2-year to 12 -year of age in human. The adolescence period in rat and human begin at 45 -day to 90 -day and 12-year to 16year of age, respectively. The post-weaning age is a critical period of various neuroendocrine developments where the hypothalamus-pituitary-gonadal axis is still immature and therefore the levels of sex hormones in the body are relatively low [39]. This is why children are more susceptible to the toxic effects of BPA since bisphenol A toxicity may interfere with the maturation of hypothalamus-pituitary-gonadal axis through a variety of pathway including food and drinking water. Since BPA was detected in infant formula $[40,41]$ and leaching from polycarbonate baby bottles during washing, boiling and brushing $[42,43]$, the general population has become more concern over BPA exposure and its potential effects.

Several studies have reported that BPA exposure in rodent models correlates with weight gain $[14,16,44]$ although other studies have not found this correlation [45-47]. In the present study, BPA caused a slight increase in the body weight though not significantly different from the $\mathrm{CO}$ rats. Thus, our results were in agreement with the latter studies. The discrepancy in these results could be due to differences in the sensitivity of the strain used to BPA exposure [48], dose selection, route of exposure, time window of exposure (age) and duration of exposure $[49,50]$. 


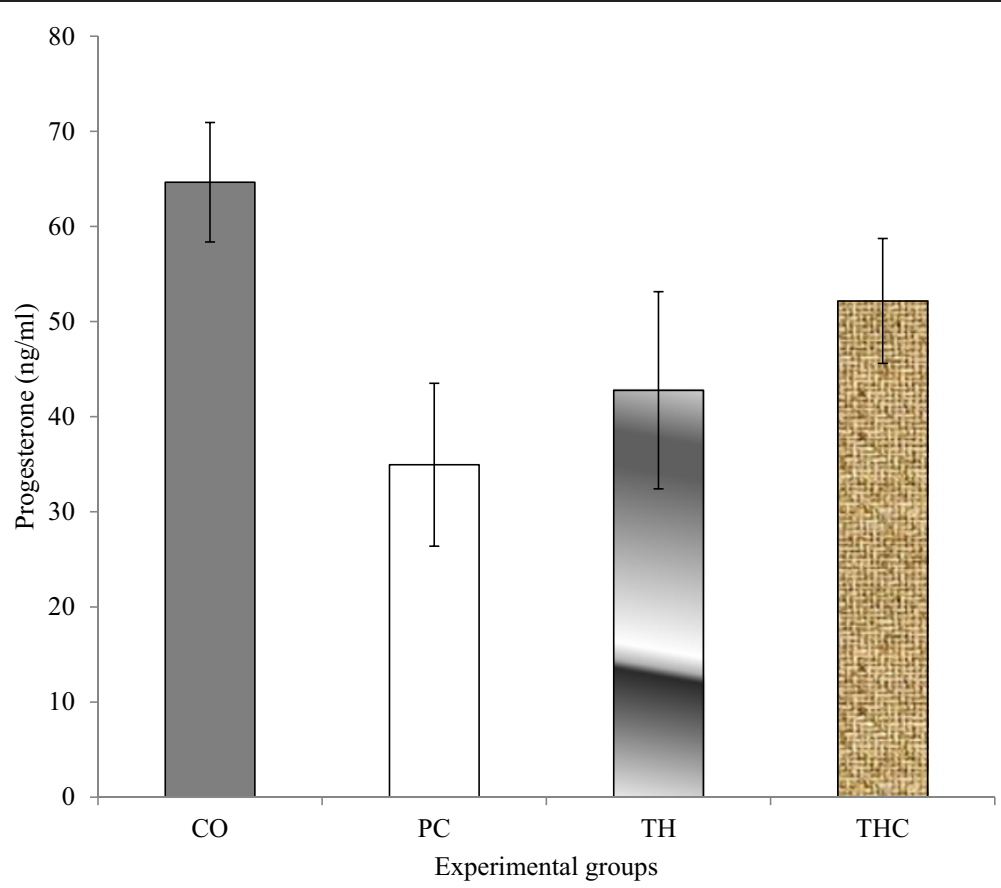

Figure 4 Serum progesterone $\left(\mathbf{P}_{4}\right)$ levels in all experimental groups. The data were presented as Mean \pm S.E.M. There were no significant difference in progesterone levels between all experimental groups. $\mathrm{CO}=$ Negative control group administered with vehicle (corn oil). PC $=$ Positive control group administered with BPA at $10 \mathrm{mg} / \mathrm{kg}$ body weight. TH = Tualang honey group administered with Tualang honey at $200 \mathrm{mg} / \mathrm{kg}$ body weight + BPA at $10 \mathrm{mg} / \mathrm{kg}$ body weight. THC = Tualang honey control group administered with Tualang honey at $200 \mathrm{mg} / \mathrm{kg}$ body weight.

The term 'estrous' refers to the special period of sexual desire of the female rats [51]. Generally, the sexual maturation (puberty) of female rats occurs between six to eight weeks of age (42 to 56 -old days) and assessed by the formation of the external orifice of the vaginal canal [52] where the first estrous cycle begins approximately one week after vaginal opening. The onset of puberty results from establishment of both amplitude and frequency of hypothalamic and pituitary hormones pulses that stimulate the synthesis and cyclic secretion of ovarian steroid hormone [51]. As reported in several studies $[11,14,16,44,50,53,54]$, estrous cyclicity was disrupted by BPA in rodent models. It was observed that the estrous cycles became persistent diestrus, persistent estrous or ultimately to acyclicity. BPA-exposed rodents were also reported to have earlier onset of puberty based on vaginal opening. Our study also showed persistent diestrus and earlier onset of vaginal opening in BPA-exposed rats. Interestingly, we observed an improvement in the percentage of normal estrous cycle in BPAexposed rats treated with Tualang honey.

Disruption of normal estrous cycle is an indicator to alteration in the function of the hypothalamic-pituitary axis in BPA-exposed female rats [16] by interfering with the normal production of gonadotrophin releasing hormone $(\mathrm{GnRH})$ and thereby decreasing the secretion of FSH and LH. Anatomical evidence reveals that neurons in sexually dimorphic regions are responsible for primary hypothalamic signal for gonadotropin synthesis and secretion and the drive for LH surge required for ovulation $[55,56]$. Study by Petersen and Barraclough (1989), described that sexually dimorphic region in the brain, namely the rostral preoptic area, is crucial for normal estrous cyclicity and estrogen positive feedback [57]. This region contains estrogen receptors (ERs) and aromatase that are able to convert in situ testosterone to estrogen in females or males during critical periods of sexual differentiation [58]. Thus, exogenous estrogenic compounds like BPA can influence this region during development by binding to ERs. In BPA-exposed female rats, the stimulation on hypothalamus was increased (hypothalamic maturation and an accelerated GnRH pulse frequency) and inhibition on pituitary (reduced LH levels). These resulted in earlier vaginal opening and first estrous cycle, suggesting the effects of accelerated hypothalamic maturation that occurred in early life due to BPA. In this study, it was found that treatment with Tualang honey could hinder the disruption in normal estrous cycle via the reversal of FSH and $\mathrm{LH}$ hormones to their normal levels, which is reflected in the normalization of $\mathrm{GnRH}$ production in the brain. These results are also in line with the improvement of morphological findings in the ovarian follicles. All these improvements could be explained by the fact that honey contains bioactive molecules 

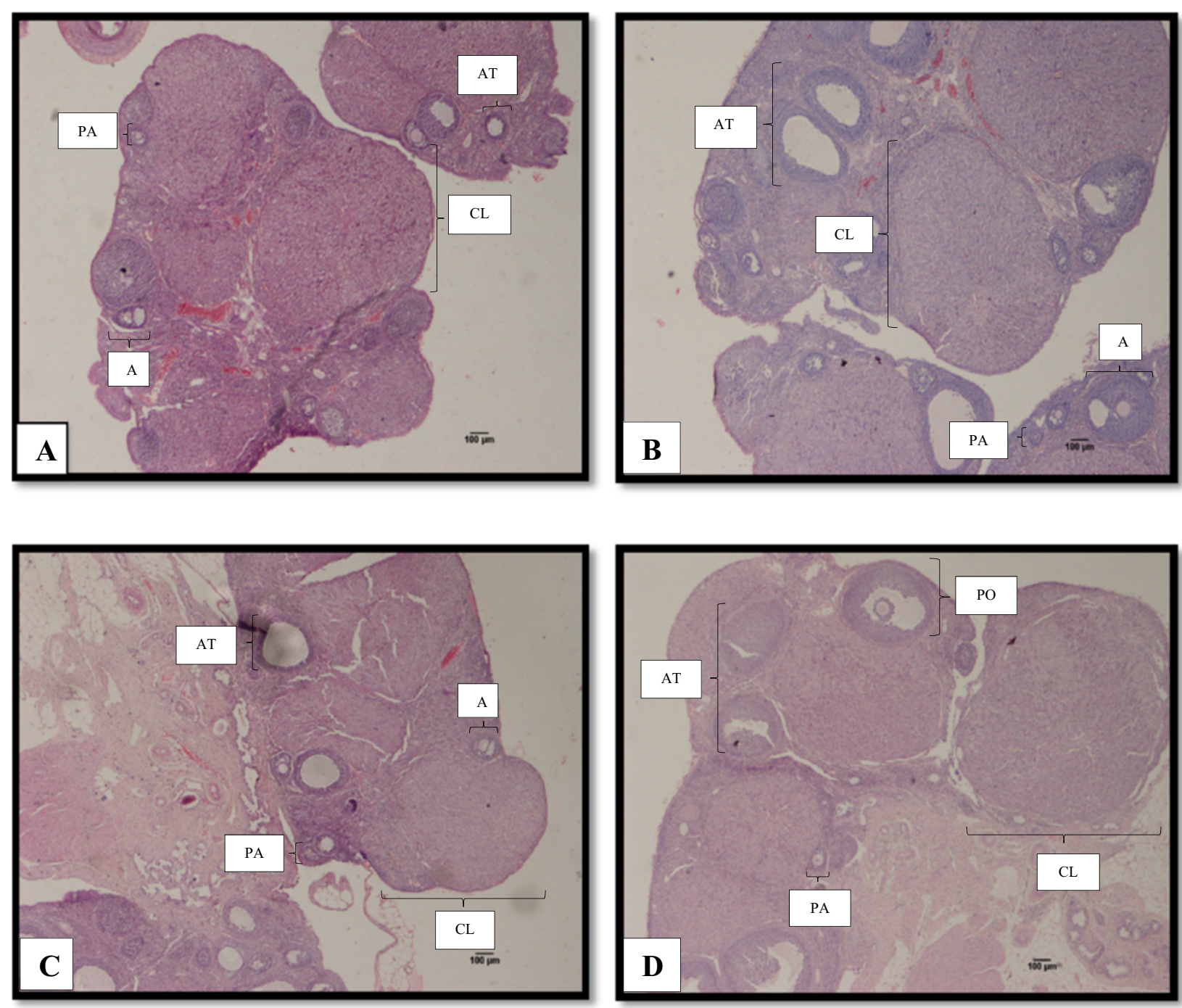

Figure 5 Photomicrographs of representative ovarian section in experimental groups. A) CO group B) PC group C) TH group D) THC group. Staining with H\&E. PA: Preantral; A: Antral; At: Atretic; CL: Corpus luteum; PO: Preovulatory. Scale bar $=100 \mu \mathrm{m}$. CO = Negative control group administered with vehicle (corn oil). PC = Positive control group administered with BPA at $10 \mathrm{mg} / \mathrm{kg}$ body weight. TH=Tualang honey group administered with Tualang honey at $200 \mathrm{mg} / \mathrm{kg}$ body weight + BPA at $10 \mathrm{mg} / \mathrm{kg}$ body weight. THC = Tualang honey control group administered with Tualang honey at $200 \mathrm{mg} / \mathrm{kg}$ body weight.

that exert protective effects via their estrogenic properties, namely the flavonols. Flavonols are phytochemicals and originate from a subfamily of flavonoids with many biological activities. Quercetin and kaempferol are the two main naturally-occuring flavonols which share structural similarities with $17 \beta$-estradiol, and therefore have potential estrogenic effects [59]. Thus, their beneficial effect in the improvement of the function of hypothalamic-pituitary axis is possibly due to their ability to bind to ERs in rostral preoptic region of brain, competing with other xenoestrogenic like BPA. This hypothesis of the protective effects of flavonols via their estrogenic mechanism is also supported by previous studies $[60,61]$. Indeed, it is possible that both flavonols in Tualang honey are accountable as the modulators of xenoestrogenic effects of BPA in the female reproductive functions.

In this study, decreased levels of serum LH were observed in BPA-treated rats compared to control group. The decrease in serum LH level may result in the formation of cystic follicle (anovulation follicle) and consequently lack of corpora lutea, reflecting reduction in the progesterone levels [12]. Cystic follicle is formed from anovulatory follicle surrounded by thin layers of granulose cells with non-detectable theca cell layers [62]. Others claimed that large antral-like follicles do not support ovulation process in the ovary [11]. Our results is in agreement with the previous study that the total numbers of follicles in BPA-exposed rats have a positive correlation with the 


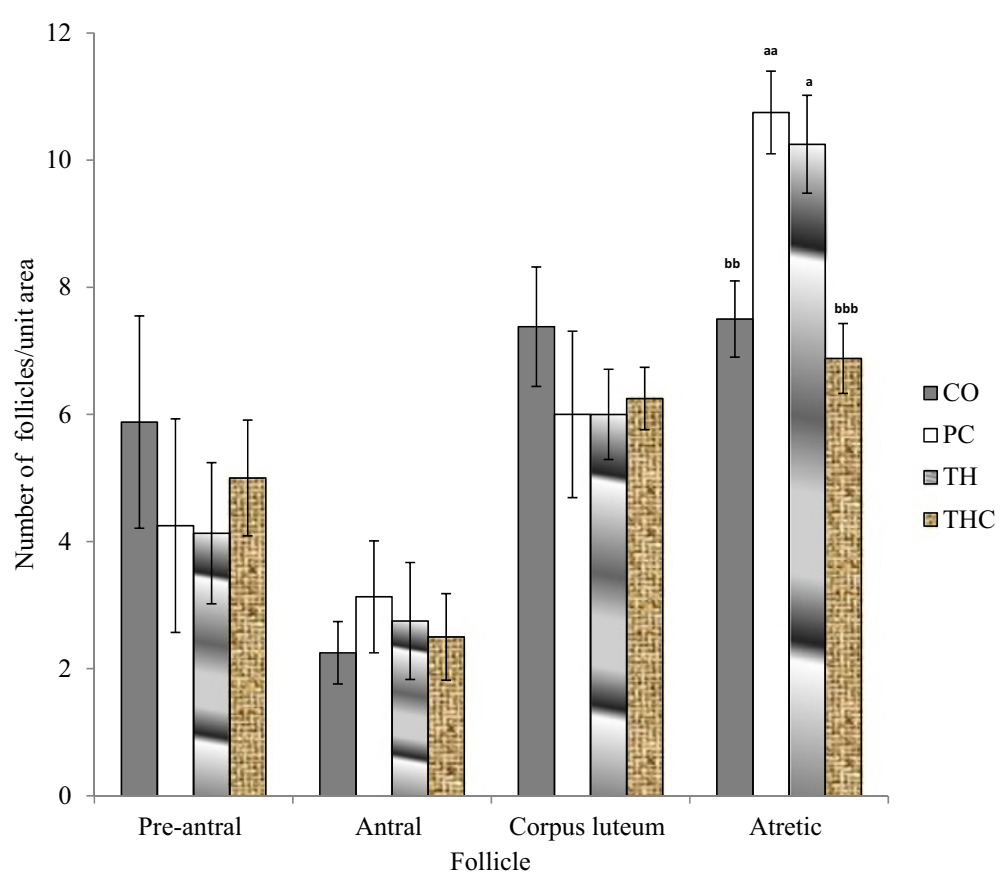

Figure 6 Number of different types of follicles in all experimental groups. The data were presented as Mean \pm S.E.M. Means with different superscripts are significantly different. ${ }^{a} \mathrm{P}<0.05,{ }^{\text {aa }} \mathrm{P}<0.01$ versus negative control group $(\mathrm{CO})$ and ${ }^{\mathrm{bb}} \mathrm{P}<0.01$, ${ }^{\mathrm{bbb}} \mathrm{P}<0.001$ versus positive control group (PC). There were no significant differences in pre-antral, antral and corpus luteum between all groups. $\mathrm{CO}=$ Negative control group administered with vehicle (corn oil). PC = Positive control group administered with BPA at $10 \mathrm{mg} / \mathrm{kg}$ body weight. TH=Tualang honey group administered with Tualang honey at $200 \mathrm{mg} / \mathrm{kg}$ body weight + BPA at $10 \mathrm{mg} / \mathrm{kg}$ body weight. THC = Tualang honey control group administered with Tualang honey at $200 \mathrm{mg} / \mathrm{kg}$ body weight.

ovarian weight [63]. The number of preantral follicles in BPA-exposed rat was reduced or less compared to control rat, indicating that exposure to BPA interfered with the normal development of growing follicles in the ovary. This result is similar to previous study that used prepubertal female rat as an animal model [34]. Even with the disruption in normal ovulation process and in persistent diestrous phase, some follicles still progressed but without ovulation, followed by atresia, as reflected by the increase in the number of atretic follicles in BPAexposed rats compared to the control rat. Indeed, our results showed a trend towards an increase in the number of antral follicle as well as a decrease in the number of corpora lutea in BPA-treated rats compared to control group. These results are in agreement with previous finding that also showed reduction in the number of ovulated oocytes [14]. As for the BPA-exposed rats treated with Tualang honey, the morphological abnormalities of the ovary were reduced and the number of atretic follicles was also slightly lower.

Lipid peroxidation and generation of free radicals are the two major contributors for the toxicity effects of BPA [35]. Studies have also reported that BPA was shown to induce OS in different tissues rodents [19] and could promote OS and inflammation in women [17]. In particular, OS plays an important role in the pathologies of female infertility problems that influence the entire reproductive life span by affecting oocyte maturation, ovarian steroidegenesis, ovulation, luteolysis and luteal maintenance in pregnancy [64]. The metabolite groups of BPA such as quinones (phenolic precursors), metal complexes (complexors), aromatic nitro compounds (reduced hydroxylamine and nitroso derivatives) and conjugated imines (iminium species) can incorporate with electron transfer (ET) to induce ROS [65]. Small quantities of oxidized metabolite can act as catalyst in a redox manner with generation of large quantities of ROS that result in OS. Thus, ET-ROS-OS framework provide reasonable and convenience evidence that BPA is a toxic agent [65]. OS is an important exacerbating factor for diverse pathological processes which can lead to deoxyribonucleic acid (DNA) damage, mutations, cellular injury, oncogenesis and aging process [66]. The genotoxicity effects of BPA have been widely tested in vitro and in vivo studies $[67,68]$. The comet assays shows that BPA caused DNA fragmentation in blood lympocytes and structural chromosome aberrations in bone-marrow cells [69]. Other studies claimed that BPA induce lipid peroxidation, DNA fragmention in spermatozoa and up-regulate clusterin expression in atrophic prostate epithelial cells [70], DNA damage in germ cells [71] and MCF-7 cells [72]. Recently, Tualang honey was reported for its anticancer activity in breast cancer cell 
lines via the upregulation of double strand DNA repair enzymes that preserve cellular DNA integrity [73] or by promoting apoptotic cell death [74]. In ultraviolet (UV) B radiation study, treatment with Tualang honey to PAM212 cells can result in the reduction of the number of cyclobutane pyrimidine dimers and 8-oxo-dG-positive cells (biomarkers of DNA damage) due to improvement in DNA repair [75]. In agreement with these findings, studies on Buckwheat honey [76] and honey from arid regions [77] also demonstrated their protective effects on DNA damage. In general, the reducing power, DPPH radical scavenging activity, metal chelating activity and hydroxyl radical scavenging activities are all attributed to the antioxidants mechanisms in honey in preventing DNA damage.

Interestingly, Tualang honey has also been claimed as an ideal antioxidant with both aqueous and lipophilic properties that enable it to easily penetrate biological membranes and consequently act at different cellular levels of the cells [22]. The combination of endogenous antioxidants and the antioxidants from natural products plays an important role in the protective antioxidant mechanism in the body system against OS. When BPAexposed rats are treated with Tualang honey, there was a marked improvement in the morphological abnormalities in ovarian follicules. In addition to the reduced number of atretic follicles, there was also improvement in the percentage of animals with normal estrous cycle compared to BPA-exposed rats without Tualang honey treatment. These results illustrated the ability of Tualang honey as a potential antigenotoxic mediator that is able to reduce ovarian toxicity, hence demonstrating its contribution to the protective mechanism against the genotoxic effects induced by BPA.

\section{Conclusions}

In conclusion, Tualang honey has a potential role in reducing BPA-induced ovarian toxicity by reducing the morphological abnormalities of the ovarian follicles and improving the normal estrous cycle.

\section{Abbreviations}

EDCs: Endocrine-disrupting chemicals; BPA: Bisphenol-A; VEGF: Vascular endothelial growth factor; PCOS: Polycystic ovaries; LH: Luteinizing hormone; FSH: Follicle stimulating hormone; $E_{2}$ : 17ß-Estradiol; $\mathrm{P}_{4}$ : Progesterone; OS: Oxidative stress; DNA: Deoxyribonucleic acid; DPPH: 1,1-diphenyl-2-picrylhydrazyl; OSCC: Oral squamous cell carcinoma; HOS: Human osteosarcoma; CO: Negative control group; PC: Positive control group; TH: Tualang honey group; THC: Tualang honey control group.
}

\section{Competing interests}

The authors declare that they have no competing interests.

\section{Authors' contributions}

SMZ (1st author) carried out the lab work, analysis the data and drafted the manuscript. NMK (3rd author) designed and led the whole study, main-supervisor to $S M Z$, principal investigator of grant, provided guidance in histological lab work and data analysis and finalized the revised manuscript. SO (2nd author) read and revised the manuscript. All authors read and approved the final manuscript.

\section{Authors' information}

NMK (PhD) is a Professor in Deparment of Anatomy, Faculty of Medicine, University of Malaya. Her areas of expertise including developmental anatomy, cytology (histology, electron microscopy, immunocytochemistry) and toxicology (endorine disrupting chemicals).

$\mathrm{SO}(\mathrm{PhD})$ is a senior lecturer in Department of Molecular Medicine, Faculty of Medicine, University of Malaya. Her areas of expertise including cellular immunology and drug discovery.

SMZ (Masters) is a postgraduate student in Department of Anatomy, Faculty of Medicine, University of Malaya. Her research project focus on preventing or ameliorating effects of natural products on BPA-induced reproductive toxicity in rats.

\section{Acknowledgements}

The authors would like to acknowledge the University of Malaya for providing a postgraduate research grant (No: PG087-2012B), Universiti Putra Malaysia and Ministry of Higher Education for the financial assistance to the first author Siti Sarah Mohamad Zaid. Sincere thanks to all staff of the Department of Anatomy, Faculty of Medicine, University of Malaya.

\section{Author details}

${ }^{1}$ Department of Anatomy, Faculty of Medicine, University of Malaya, 50603 Kuala Lumpur, Malaysia. ${ }^{2}$ Department of Molecular Medicine, Faculty of Medicine, University of Malaya, 50603 Kuala Lumpur, Malaysia. ${ }^{3}$ Department of Environmental Sciences, Faculty of Environmental Studies, 43400, UPM Serdang, Selangor, Malaysia.

Received: 23 May 2014 Accepted: 9 December 2014 Published: 17 December 2014

\section{References}

1. Borgeest C, Greenfeld C, Tomic D, Flaws JA: The effects of endocrine disrupting chemicals on the ovary. Front Biosci 2002, 7:1941-1948.

2. Richter CA, Birnbaum LS, Farabollini F, Newbold RR, Rubin BS, Talsness CE, Vandenbergh JG, Walser-Kuntz DR, vom Saal FS: In vivo effects of bisphenol A in laboratory rodent studies. Reprod Toxicol 2007, 24(2):199-224.

3. Staples CA, Dorn PB, Klecka GM, O'Block ST, Harris LR: A review of the environmental fate, effects, and exposures of bisphenol A. Chemosphere 1998, 36(10):2149-2173.

4. Braun JM, Hauser R: Bisphenol A and children's health. Curr Opin Pediatr 2011, 23(2):233-239.

5. Grasselli F, Baratta L, Baioni L, Bussolati S, Ramoni R, Grolli S, Basini G: Bisphenol A disrupts granulosa cell function. Domest Anim Endocrinol 2009, 39(1):34-39.

6. Ikezuki Y, Tsutsumi O, Takai Y, Kamei Y, Taketani Y: Determination of bisphenol A concentrations in human biological fluids reveals significant early prenatal exposure. Hum Reprod 2002, 17(11):2839-2841.

7. Kuroda N, Kinoshita Y, Sun Y, Wada M, Kishikawa N, Nakashima K, Makino T, Nakazawa $\mathrm{H}$ : Measurement of bisphenol A levels in human blood serum and ascitic fluid by HPLC using a fluorescent labeling reagent. J Pharm Biomed Anal 2003, 30(6):1743-1749.

8. Sun Y, Irie M, Kishikawa N, Wada M, Kuroda N, Nakashima K: Determination of bisphenol $\mathrm{A}$ in human breast milk by HPLC with column-switching and fluorescence detection. Biomed Chromatogr 2004, 18(8):501-507.

9. Yang M, Kim SY, Chang SS, Lee IS, Kawamoto T: Urinary concentrations of bisphenol A in relation to biomarkers of sensitivity and effect and endocrine-related health effects. Environ Mol Mutagen 2006, 47(8):571-578.

10. Calafat AM, Kuklenyik Z, Reidy JA, Caudill SP, Ekong J, Needham LL: Urinary concentrations of bisphenol A and 4-nonylphenol in a human reference population. Environ Health Perspect 2005, 113(4):391-395.

11. Adewale HB, Jefferson WN, Newbold RR, Patisaul HB: Neonatal bisphenol-a exposure alters rat reproductive development and ovarian morphology without impairing activation of gonadotropin-releasing hormone neurons. Biol Reprod 2009, 81(4):690-699.

12. Zhou W, Liu J, Liao L, Han S: Effect of bisphenol A on steroid hormone production in rat ovarian theca-interstitial and granulosa cells. Mol Cell Endocrinol 2008, 283(1-2):12-18.

13. Rodriguez HA, Santambrosio N, Santamaria CG, Munoz-de-Toro M, Luque EH: Neonatal exposure to bisphenol A reduces the pool of primordial follicles in the rat ovary. Reprod Toxicol 2010, 30(4):550-557. 
14. Markey CM, Coombs MA, Sonnenschein C, Soto AM: Mammalian development in a changing environment: exposure to endocrine disruptors reveals the developmental plasticity of steroid-hormone target organs. Evol Dev 2003, 5(1):67-75.

15. Kato $H$, Ota $T$, Furuhashi $T$, Ohta $Y$, Iguchi $T$ : Changes in reproductive organs of female rats treated with bisphenol A during the neonatal period. Reprod Toxicol 2003, 17(3):283-288.

16. Rubin BS, Murray MK, Damassa DA, King JC, Soto AM: Perinatal exposure to low doses of bisphenol A affects body weight, patterns of estrous cyclicity, and plasma LH levels. Environ Health Perspect 2001, 109(7):675-680.

17. Yang YJ, Hong YC, Oh SY, Park MS, Kim H, Leem JH, Ha EH: Bisphenol A exposure is associated with oxidative stress and inflammation in postmenopausal women. Environ Res 2009, 109(6):797-801

18. Kabuto H, Hasuike S, Minagawa N, Shishibori T: Effects of bisphenol A on the metabolisms of active oxygen species in mouse tissues. Environ Res 2003, 93(1):31-35.

19. Bindhumol V, Chitra KC, Mathur PP: Bisphenol A induces reactive oxygen species generation in the liver of male rats. Toxicology 2003, 188(2-3):117-124.

20. Poeggeler B, Reiter RJ, Tan DX, Chen LD, Manchester LC: Melatonin, hydroxyl radical-mediated oxidative damage, and aging: a hypothesis. J Pineal Res 1993, 14(4):151-168.

21. Al-Mamary M, Al-Meeri A, Al-Habori M: Antioxidant activities and total phenolics of different types of honey. Nutr Res 2002, 22(9):1041-1047.

22. Aljadi AM, Kamaruddin MY: Evaluation of the phenolic contents and antioxidant capacities of two Malaysian floral honeys. Food Chem 2004, 84(4):513-518

23. Mahaneem M, Sirajudeen KNS, Swamy M, Nik SY, Siti AS: Studies on antioxidant properties of Tualang honey. Afr J Tradit Complement Altern Med 2010, 7(1):59-63.

24. Khalil MI, Alam N, Moniruzzaman M, Sulaiman SA, Gan SH: Phenolic acid composition and antioxidant properties of Malaysian honeys. J Food Sci 2011, 76(6):C921-C928.

25. Erejuwa OO, Sulaiman SA, Ab Wahab MS, Sirajudeen KN, Salleh S, Gurtu S: Honey supplementation in spontaneously hypertensive rats elicits antihypertensive effect via amelioration of renal oxidative stress. Oxid Med Cell Longev 2012, 2012:374037.

26. Erejuwa OO, Sulaiman SA, Wahab MS, Salam SK, Salleh MS, Gurtu S: Antioxidant protective effect of glibenclamide and metformin in combination with honey in pancreas of streptozotocin-induced diabetic rats. Int J Mol Sci 2010, 11(5):2056-2066.

27. Zaid SS, Sulaiman SA, Sirajudeen KN, Othman NH: The effects of Tualang honey on female reproductive organs, tibia bone and hormonal profile in ovariectomised rats-animal model for menopause. BMC Complement Altern Med 2010, 10:82

28. Zaid SS, Sulaiman SA, Othman NH, Soelaiman IN, Shuid AN, Mohamad N Muhamad N: Protective effects of Tualang honey on bone structure in experimental postmenopausal rats. Clinics (Sao Paulo) 2012, 67(7):779-784.

29. Mahaneem M, Siti AS, Hasnan J, Kuttulebbai NMS: Antioxidant protective effect of honey in cigaratte smoke-induced testicular damage in rats. Int J Mol Med 2011, 12:5508-5521.

30. Abdulmlik AG, Nor HO, Mohammed NK, Noorliza, Rajan S: Antiproliferative effect of Tualang honey on oral squamous cell carcinoma and osteosarcoma cell lines. BMC Complement Altern Med 2010, 10(49):1-7.

31. Mohamad SNS, Ahmad SH, Siew HG, Shaharum S: Antiproliferative effect of methanolic extraction of Tualang honey on human keloid fibroblasts. BMC Complement Altern Med 2011, 11(82):1-8.

32. Suzuki A, Sugihara A, Uchida K, Sato T, Ohta Y, Katsu Y, Watanabe H, Iguchi T: Developmental effects of perinatal exposure to bisphenol-A and diethylstilbestrol on reproductive organs in female mice. Reprod Toxicol 2002, 16(2):107-116.

33. Okuda K, Takiguchi M, Yoshihara S: In vivo estrogenic potential of 4-methyl-2,4-bis(4-hydroxyphenyl)pent-1-ene, an active metabolite of bisphenol A, in uterus of ovariectomized rat. Toxicol Lett 2010, 197(1):7-11.

34. Li Y, Zhang W, Liu J, Wang W, Li H, Zhu J, Weng S, Xiao S, Wu T: Prepubertal bisphenol A exposure interferes with ovarian follicle development and its relevant gene expression. Reprod Toxicol 2014, 44:33-40.

35. Anjum S, Rahman S, Kaur M, Ahmad F, Rashid H, Ansari RA, Raisuddin S: Melatonin ameliorates bisphenol A-induced biochemical toxicity in testicular mitochondria of mouse. Food Chem Toxicol 2011, 49(11):2849-2854.
36. Zhuang $X L$, Fu YC, Xu JJ, Kong XX, Chen ZG, Luo LL: Effects of genistein on ovarian follicular development and ovarian life span in rats. Fitoterapia 2010, 81(8):998-1002.

37. Michael B, Yano B, Sellers RS, Perry R, Morton D, Roome N, Johnson JK Schafer K, Pitsch S: Evaluation of organ weights for rodent and non-rodent toxicity studies: a review of regulatory guidelines and a survey of current practices. Toxicol Pathol 2007, 35(5):742-750.

38. Hood RD: Developmental and Reproductive Toxicology: A Practical Approach. United States of America: CRC Press; 2006.

39. Li Y, Zhang W, Liu J, Wang W, Li H, Zhu J, Weng S, Xiao S, Wu T: Prepubertal bisphenol A exposure interferes with ovarian follicle development and its relevant gene expression. Reprod Toxicol 2013, 44:33-40.

40. Biles JE, McNeal TP, Begley TH: Determination of bisphenol A migrating from epoxy can coatings to infant formula liquid concentrates. J Agric Food Chem 1997, 45:4691-4700.

41. Kuo HW, Ding WH: Trace determination of bisphenol A and phytoestrogens in infant formula powders by gas chromatography-mass spectrometry. J Chromatogr A 2004, 1027(1-2):67-74.

42. Sun Y, Wada M, Al-Dirbashi O, Kuroda N, Nakazawa H, Nakashima K: High-performance liquid chromatography with peroxyoxalate chemiluminescence detection of bisphenol A migrated from polycarbonate baby bottles using 4-(4,5-diphenyl-1H-imidazol-2-yl) benzoyl chloride as a label. J Chromatogr B Biomed Sci Appl 2000, 749(1):49-56.

43. Brede C, Fjeldal P, Skjevrak I, Herikstad H: Increased migration levels of bisphenol A from polycarbonate baby bottles after dishwashing, boiling and brushing. Food Addit Contam 2003, 20(7):684-689.

44. Howdeshell KL, Hotchkiss AK, Thayer KA, Vandenbergh JG, vom Saal FS, Vandenbergh JG, Vom Saal FS: Exposure to bisphenol A advances puberty. Nature 1999, 401(6755):763-764.

45. Kwon S, Stedman DB, Elswick BA, Cattley RC, Welsch F: Pubertal development and reproductive functions of $\mathrm{Crl}: \mathrm{CD}$ BR Sprague-Dawley rats exposed to bisphenol $A$ during prenatal and postnatal development. Toxicol Sci 2000, 55(2):399-406.

46. Tinwell H, Haseman J, Lefevre PA, Wallis N, Ashby J: Normal sexual development of two strains of rat exposed in utero to low doses of bisphenol A. Toxicol Sci 2002, 68(2):339-348.

47. Tan BL, Kassim NM, Mohd MA: Assessment of pubertal development in juvenile male rats after sub-acute exposure to bisphenol $A$ and nonylphenol. Toxicol Lett 2003, 143(3):261-270.

48. Steinmetz R, Mitchner NA, Grant A, Allen DL, Bigsby RM, Ben-Jonathan N: The xenoestrogen bisphenol $A$ induces growth, differentiation, and c-fos gene expression in the female reproductive tract. Endocrinology 1998, 139(6):2741-2747.

49. Allard P, Colaiacovo MP: Bisphenol A. In Reproductive and Developmental Toxicology. Edited by Gupta RC. USA: Elsevier; 2011:673-686.

50. Mendoza-Rodriguez CA, Garcia-Guzman M, Baranda-Avila N, Morimoto S, Perrot-Applanat M, Cerbon M: Administration of bisphenol A to dams during perinatal period modifies molecular and morphological reproductive parameters of the offspring. Reprod Toxicol 2011, 31(2):177-183.

51. Westwood FR: The female rat reproductive cycle: a practical histological guide to staging. Toxicol Pathol 2008, 36(3):375-384.

52. Li S, Davis B: Evaluating rodent vaginal and uterine histology in toxicity studies. Birth Defects Res B Dev Reprod Toxicol 2007, 80(3):246-252.

53. Fernandez M, Bianchi M, Lux-Lantos V, Libertun C: Neonatal exposure to bisphenol a alters reproductive parameters and gonadotropin releasing hormone signaling in female rats. Environ Health Perspect 2009, 117(5):757-762.

54. Nikaido Y, Yoshizawa K, Danbara N, Tsujita-Kyutoku M, Yuri T, Uehara N, Tsubura A: Effects of maternal xenoestrogen exposure on development of the reproductive tract and mammary gland in female CD-1 mouse offspring. Reprod Toxicol 2004, 18(6):803-811.

55. Petersen SL, Ottem EN, Carpenter CD: Direct and indirect regulation of gonadotropin-releasing hormone neurons by estradiol. Biol Reprod 2003 69(6):1771-1778.

56. Simonian SX, Spratt DP, Herbison AE: Identification and characterization of estrogen receptor alpha-containing neurons projecting to the vicinity of the gonadotropin-releasing hormone perikarya in the rostral preoptic area of the rat. J Comp Neurol 1999, 411(2):346-358.

57. Petersen SL, Barraclough CA: Suppression of spontaneous LH surges in estrogen-treated ovariectomized rats by microimplants of antiestrogens into the preoptic brain. Brain Res 1989, 484(1-2):279-289. 
58. McEwen BS, Alves SE: Estrogen actions in the central nervous system. Endocr Rev 1999, 20(3):279-307.

59. Wattel A, Kamel S, Mentaverri R, Lorget F, Prouillet C, Petit JP, Fardelonne P, Brazier M: Potent inhibitory effect of naturally occurring flavonoids quercetin and kaempferol on in vitro osteoclastic bone resorption. Biochem Pharmacol 2003, 65(1):35-42.

60. Hertog MG, Hollman PC, Katan MB, Kromhout D: Intake of potentially anticarcinogenic flavonoids and their determinants in adults in The Netherlands. Nutr Cancer 1993, 20(1):21-29.

61. Hertog MGL, Hollman PCH, Katan MBJ: Content of potentially anticarcinogenic flavonoids of 28 vegetables and fruits commonly consumed in The Netherlands. Agr Food Chem 1992, 1992(40):2379-2383.

62. Fernandez M, Bourguignon N, Lux-Lantos V, Libertun C: Neonatal exposure to bisphenol a and reproductive and endocrine alterations resembling the polycystic ovarian syndrome in adult rats. Environ Health Perspect 2010, 118(9):1217-1222.

63. Murasawa M, Takahashi T, Nishimoto H, Yamamoto S, Hamano S, Tetsuka M: Relationship between ovarian weight and follicular population in heifers. J Reprod Dev 2005, 51(5):689-693.

64. Yi B, Kasai H, Lee HS, Kang Y, Park JY, Yang M: Inhibition by wheat sprout (Triticum aestivum) juice of bisphenol A-induced oxidative stress in young women. Mutat Res 2011, 724(1-2):64-68.

65. Kovacic P: How safe is bisphenol A? Fundamentals of toxicity: metabolism, electron transfer and oxidative stress. Med Hypotheses 2010, 75(1):1-4.

66. Zahin M, Ahmad I, Aqil F: Antioxidant and antimutagenic activity of Carum copticum fruit extracts. Toxicol In Vitro 2010, 24(4):1243-1249.

67. Hilliard CA, Armstrong MJ, Bradt Cl, Hill RB, Greenwood SK, Galloway SM: Chromosome aberrations in vitro related to cytotoxicity of nonmutagenic chemicals and metabolic poisons. Environ Mol Mutagen 1998, 31(4):316-326

68. Naik P, Vijayalaxmi KK: Cytogenetic evaluation for genotoxicity of bisphenol-A in bone marrow cells of Swiss albino mice. Mutat Res 2012, 676(1-2):106-112

69. Tiwari D, Kamble J, Chilgunde S, Patil P, Maru G, Kawle D, Bhartiya U, Joseph L, Vanage $\mathrm{G}$ : Clastogenic and mutagenic effects of bisphenol $\mathrm{A}$ : an endocrine disruptor. Mutat Res 2012, 743(1-2):83-90.

70. De Flora S, Micale RT, La Maestra S, Izzotti A, D'Agostini F, Camoirano A, Davoli SA, Troglio MG, Rizzi F, Davalli P, Bettuzzi Y: Upregulation of clusterin in prostate and DNA damage in spermatozoa from bisphenol A-treated rats and formation of DNA adducts in cultured human prostatic cells. Toxicol Sci 2011, 122(1):45-51.

71. Wu HJ, Liu C, Duan WX, Xu SC, He MD, Chen CH, Wang Y, Zhou Z, Yu ZP, Zhang $L$, Chen $Y$ : Melatonin ameliorates bisphenol A-induced DNA damage in the germ cells of adult male rats. Mutat Res 2012, 752(1-2):57-67.

72. Iso T, Watanabe T, Iwamoto T, Shimamoto A, Furuichi Y: DNA damage caused by bisphenol A and estradiol through estrogenic activity. Biol Pharm Bull 2006, 29(2):206-210,

73. Yaacob NS, Ismail NF: Comparison of cytotoxicity and genotoxicity of 4-hydroxytamoxifen in combination with Tualang honey in MCF-7 and MCF-10A cells. BMC Complement Altern Med 2014, 14:106.

74. Yaacob NS, Nengsih A, Norazmi MN: Tualang honey promotes apoptotic cell death induced by tamoxifen in breast cancer cell lines. Evid Based Complement Alternat Med 2013. http://www.hindawi.com/journals/ecam/ 2013/989841\%

75. Ahmad I, Jimenez H, Yaacob NS, Yusuf N: Tualang honey protects keratinocytes from ultraviolet radiation-induced inflammation and DNA damage. Photochem Photobiol 2012, 88(5):1198-1204.

76. Zhou J, Li P, Cheng N, Gao H, Wang B, Wei Y, Cao W: Protective effects of buckwheat honey on DNA damage induced by hydroxyl radicals. Food Chem Toxicol 2012, 50(8):2766-2773.

77. Habib HM, Al Meqbali FT, Kamal H, Souka UD, Ibrahim WH: Bioactive components, antioxidant and DNA damage inhibitory activities of honeys from arid regions. Food Chem 2014, 153:28-34.

doi:10.1186/1472-6882-14-509

Cite this article as: Zaid et al:: Potential protective effect of Tualang

honey on BPA-induced ovarian toxicity in prepubertal rat. BMC

Complementary and Alternative Medicine 2014 14:509.

\section{Submit your next manuscript to BioMed Central and take full advantage of:}

- Convenient online submission

- Thorough peer review

- No space constraints or color figure charges

- Immediate publication on acceptance

- Inclusion in PubMed, CAS, Scopus and Google Scholar

- Research which is freely available for redistribution 